\title{
Record of glacial outburst floods in marginal zones and forelands of Scandinavian glaciations in Poland
}

\section{Zapis powodzi glacjalnych w strefach brzeżnych i na przedpolach lądolodów skandynawskich w Polsce}

Abstract

In international literature, much attention has been paid to sedimentological and geomorphological evidence of extreme floods in the forelands of both contemporary and Pleistocene glaciers and ice sheets. Reports on this subject come from areas and periods of different glaciations. In Poland such events have been documented in more than ten works. This situation prompts us to establish whether or not the occurrence of such extreme events was more frequent and widespread in the area of Poland than it has been believed to date.

The article reviews the existing research concerning within the extent of Pleistocene glaciations in Poland, which include the occurrence of high energy glacial outburst floods in the interpretation of sediments or landforms. Its objective is to determine the current state of knowledge and to indicate the direction of further research. The review also includes a study of palaeogeographic conditions of the previously documented jökulhlaup in Siedlątków, on the border of the Łask Heights.

The analysis of works and the conducted comparisons lead to the conclusion that the state of knowledge about great glacial floods in the Polish Lowland is not satisfactory. It indicates the need to undertake intense studies on the record of such events and their reconstruction as their morphogenetic role e.g. in the formation of ice-marginal valleys and other elements of glacigenic landscape is underrated.

Keywords Glacial outburst flood, jökulhlaups, high energy flow, marginal zone, subglacial flow, Scandinavian glaciations, ice-marginal valleys

Zarys treści W literaturze światowej poświęcono wiele uwagi ewidencji sedymentologicznej i morfologicznej ekstremalnych zdarzeń powodziowych zarówno na przedpolu lodowców i lądolodów współczesnych, jak i plejstoceńskich. Doniesienia na ten temat pochodzą z obszarów i okresów różnych zlodowaceń. W Polsce takie zdarzenia zostały udokumentowane w kilkunastu pracach. Sytuacja ta skłania do ustalenia, czy na obszarze Polski miała miejsce większa częstotliwość i powszechność występowania tych zdarzeń ekstremalnych niż do tej pory sądzono.

W artykule dokonano przeglądu dotychczasowych badań w zasięgu lądolodów plejstoceńskich w Polsce, które uwzględniają występowanie wysokoenergetycznych powodzi glacjalnych w interpretacji osadów lub form rzeźby. Jego celem jest określenie obecnego stanu wiedzy i wskazanie kierunków dalszych badań. Przegląd ten uzupełniono o studium warunków paleogeograficznych udokumentowanego wcześniej sedymentologicznie jökulhlaupu w Siedlątkowie na krawędzi Wysoczyzny Łaskiej.

Dokonana analiza prac i przeprowadzone zestawienia prowadzą do wniosku, że stan wiedzy na temat wielkich powodzi glacjalnych na Niżu Polskim nie jest zadowalający. Wskazuje to na potrzebę podjęcia intensywnych badań nad zapisem tego typu zdarzeń i ich rekonstrukcją, ponieważ ich rola morfogenetyczna, np. w kształtowaniu pradolin i innych elementów krajobrazu glacigenicznego jest niedoceniona.

Słowa kluczowe Powódź glacjalna, jökulhlaupy, przepływ wysokoenergetyczny, przepływ subglacjalny, strefa marginalna, zlodowacenia skandynawskie, pradoliny.

\section{Introduction}

Sedimentological, geomorphological and palaeogeographic research, as well as direct observations of hydrologic events occurring in areas covered by glaciers and ice sheets and in their immediate forelands point to the great importance of extreme flooding processes.

It has been proven many times that the intensity of glaciofluvial flooding (catastrophic floods, flash floods) often exceeds the intensity of the greatest fluvial floods, conditioned by rapid precipitation or thaws. Various terms are used to refer to them, including the Polish: powódź lodowcowa; English: glacier outburst flood, glacier lake outburst flood (GLOF), megafloods, surging flow, catastrophic meltwater flood, catastrophic ablation flood, extreme glacial floods; German: Gletscherseeausbrüche and Gletscherlauf; French: débâcle, Spanish: inundación por desborde violento de lago glaciar, and Icelandic: jökulhlaup.

The term jökulhlaup was selected in Iceland as the word to describe a rapid and brief flood which occurs in marginal zones of glaciers and in their forelands. This word comes from the Icelandic jökull (glacier) and hlaup (run, running). During such an event, the majority of water is released through subglacial tunnels. Also in this work, the term jökulhlaup refers to a flood in the proglacial area 
of an ice sheet lobe, outlet glacier or mountain glacier, initiated by a rapid release of glacial water running mainly in subglacial systems. However, it must be noted that the term jökulhlaup used in this article was formerly used as a regional name, restricted to Iceland. But with time, due to the fact that it unambiguously identifies the event of rapid and brief glacial flood, it has become more and more frequently used to refer to similar extreme events also in other areas (e.g.: Nye 1976; Maizels 1997; Tweed and Russell 1999; Carrivick 2011). Contemporary jökulhlaups in the area of Iceland are considered to be the most well-documented events of this kind (Björnsson 1992; Gudmundsson et al. 1995; Russell and Marren 1999; Tweed and Russell 1999). The difference between them and other floods is the frequently occurring dependency on volcanic phenomena (the so-called volcanogenic floods) (Pagneux et al. 2010).

Sometimes jökulhlaup is also used to refer to a large-scale flood occurring as a result of releasing a large ice-dammed lake, after the natural dam is broken (e.g. Missoula Lake in North America) (Waitt 1998). However, such phenomena last longer (months or even years) and have broader extent than jökulhlaups of Icelandic type. In such cases, it is more reasonable to use one of the following terms: megaflood, glacial megaflood or glacier lake outburst flood.

Records of glacial outburst floods in the foreland of many contemporary glaciers and Pleistocene ice sheets are documented on different continents. Literature related to Scandinavian glaciations in the Polish lands is short of sufficient synthetic studies on this subject, and it often contains only scattered information on the occurrence of floods, included merely as an addition to other research objectives. Additionally, the experience gained by the authors from research conducted in central Poland (Frydrych and Rdzany 2018) encourages them to perform a review of research conducted in the marginal zones and forelands of the consecutive Pleistocene glaciations in Poland, for which these zones are preserved either in the landscape or only in the geologic record.

The aim of this article is to compare information on the possible occurrences of such events in Poland and to determine whether they can be assumed to have occurred commonly and frequently in the Pleistocene.

\section{Traces of glacial outburst floods in the old glacial zone}

In the area of superficial occurrence of sediments and forms of the Sanian (Elsterian) glaciations (Fig. 1), no traces of extreme flooding have been documented so far. Glaciofluvial sediments are fragmentarily preserved there in river valleys, less frequently on plateaus or upland hills and it is probably because of this that they are more poorly recognised in comparison with more recent glaciations. Ice sheet of the Sanian glaciation with the largest extent (San 2 according to Mojski 2005) reached the slopes of both the Sudetes and the Carpathians, leaving behind proglacial sediments. In large valleys (the rivers of Dunajec, Wisłok and Wisłoka) vast dammed reservoirs originated, where lacustrine sediments of significant thickness were deposited (Mojski 2005). Similar events also took place in uplands. Although some sediments in the foreland of the mountains and in the uplands were thoroughly studied (e.g. Zieliński 1992; Salamon and Wójcik 2010), there are no known accounts of rapid releases of these reservoirs or other great flooding events apart from periodical shallow flooding of alluvial fans.

As regards the extent of the Odranian ice sheet (Early Saalian glaciation), exceptional studies include the work by Salamon (2009), which includes a documentation of the filling of a subglacial tunnel, which indicates the possibility of numerous occurrences of jökulhlaup type of floods. Flood sediments were documented at the Gogolin site (the western part of the Middle Triassic Ridge) (Fig. 1). Such events occurred as a result of rapid releases of water collected in subglacial reservoirs.

As regards the area covered by the Wartanian glaciation there are only mentions or brief, preliminary accounts of the occurrence of releases of kame sedimentation glaciolimnic reservoirs of different sizes in the Rawka river basin (Klajnert and Rdzany 1987; Rdzany 1997a, $1997 b, 2006,2008)$. Although these works do not use the term glacier lake outburst flood (GLOF), it was indeed an event of this kind. Evidence was presented for the formation of erosional channels and their filling, which dissect the sandy-silty glaciolimnic formations as a result of reservoir releases. Erosional structures of the channels and the planes of erosional terraces were formed after the release of large (in excess of 10 square kilometres) glaciolimnic reservoirs, which were probably interconnected. These lakes operated in the marginal zone of the decaying ice sheet, restricted by the disintegrated cover of dead ice (areal deglaciation). They were filled with alluvial fans and deltas, as well as sedimentation from suspended matter and currents. After becoming filled with sediments, mainly sands and silts of up to $30-40 \mathrm{~m}$ in thickness, they became released. For this reason, some kames reveal two-part structure in their sediment profiles: the lower part (usually thicker) is glaciolimnic, and the upper part (usually thinner - several metres) - glaciofluvial or glaciofluvial-ablative. In many places, mass releases occurred, landslides or rockfalls resulting from the withdrawal of ice support (melting of dead ice blocks). An important effect of the occurrence of the aforementioned water flows and mass movements was the cutting of erosional terraces in kame slopes and structures of gravitational deformation, which were described in the Rawka river basin. The occurrence of erosional terraces at different levels - between 8 and about $25 \mathrm{~m}$ above the contemporary bottom of the Rawka valley - indicates that releasing the reservoirs was a fairly long-lasting process, with numerous local changes of erosional bases, multiple blocking and unblocking of water (Klajnert and Rdzany 1987; Rdzany 1997a).

Within the extent of the Wartanian ice sheet (Late Saalian), sediments characteristic of extreme glaciofluvial flows in subglacial tunnels were also documented: Jaksa and Rdzany (2002) in the Rylsk Ridge (Rawa Heights) and Fard and Gruszka (2007) on the basis of investigating the esker in Uniszki near Mława (north-central Poland) (Fig. 1). Zieliński (2014) also mentions jökulhlaup sediments in this area. These sediments occur in the form of thick matrix-supported bouldery-gravelly bars. 


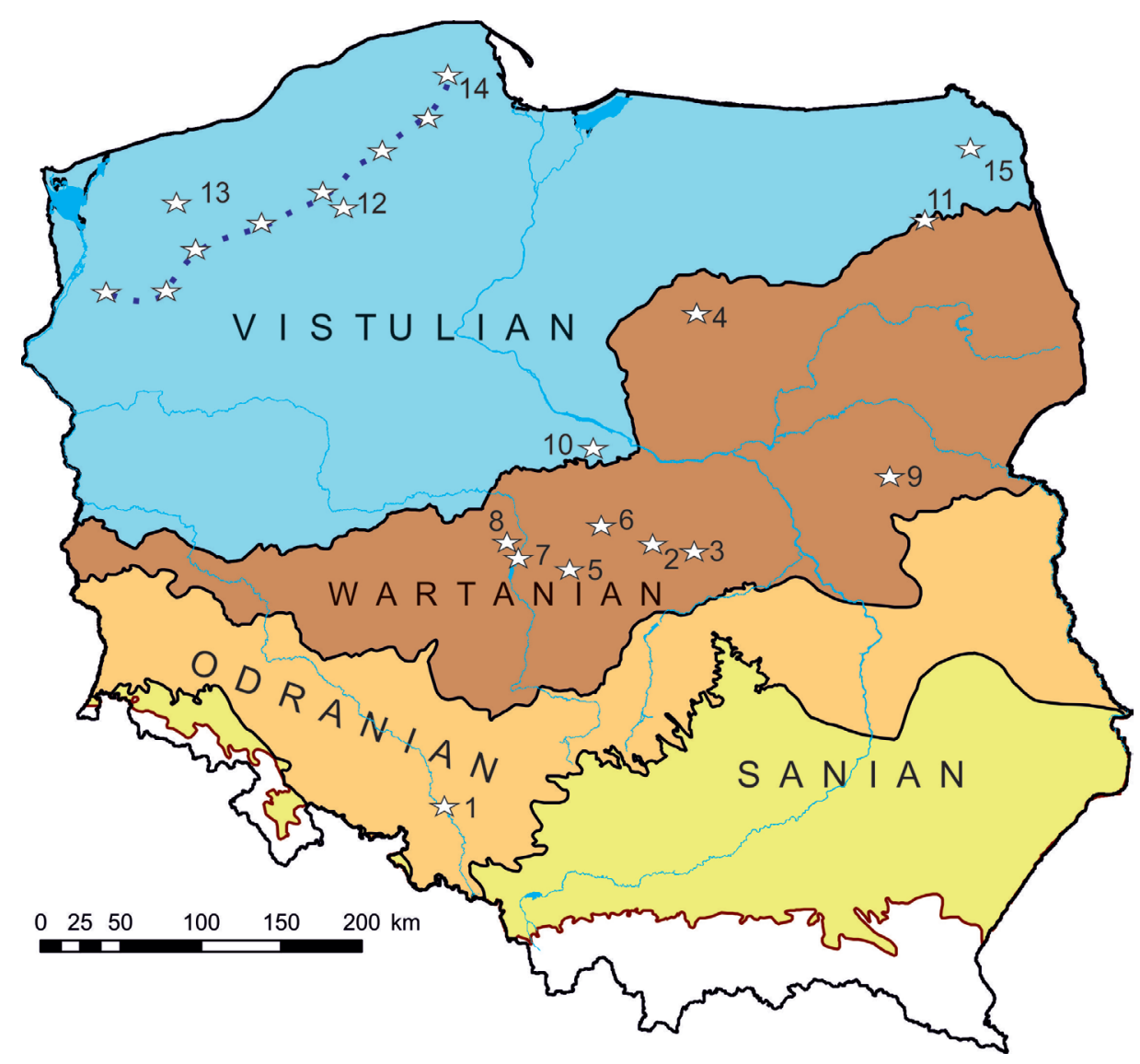

Fig. 1. Occurrence of traces of glacial floods in Poland against the background of selected glaciation extents (extents according to Mojski 2005, slightly modified)

1 - Gogolin (Salamon 2009); 2 - kame fields of the Rawka river basin (e.g. Rdzany 1997a); 3 - Rylsk esker (Jaksa and Rdzany 2002); 4 - Uniszki near Mława (Fard and Gruszka 2007; Zieliński 2014); 5 - Zygry (Jaksa 2006), 6 - Leonardów (Jaksa 2006); 7 - Siedlątków (Frydrych and Rdzany 2018); 8-Rzymsko (Frydrych 2016); 9 - Łuniew near Siedlce (Godlewska 2014); 10 - Gostynin (Roman 2016); 11 - Grajewo (Zieliński 1993 ); 12 - Szczecinek Lakeland (Zieliński 2014); 13 - Kluczkowo near Świdwin (Gruszka et al. 2011); 14 - Canyons in end moraines of the Pomeranian Phase of the Vistulian glaciation (Szafraniec 2008, 2010a, 2010b); 15 - Suwałki Lakeland (Wysota et al. 2018)

Ryc. 1. Występowanie śladów powodzi glacjalnych w Polsce na tle wybranych zasięgów zlodowaceń (zasięgi według Mojskiego 2005, nieco zmienione) 1 - Gogolin (Salamon 2009); 2 - pole kemowe w zlewni Rawki (e.g. Rdzany 1997a); 3 - oz Rylska (Jaksa i Rdzany 2002); 4 - Uniszki koło Mławy (Fard i Gruszka 2007; Zieliński 2014); 5 - Zygry (Jaksa 2006), 6 - Leonardów (Jaksa 2006); 7 - Siedlątków (Frydrych i Rdzany 2018); 8 - Rzymsko (Frydrych 2016); 9 - Łuniew koło Siedlec (Godlewska 2014); 10 - Gostynin (Roman 2016); 11 - Grajewo (Zieliński 1993); 12 - Pojezierze Szczecineckie (Zieliński 2014); 13 - Kluczkowo koło Świdwina (Gruszka i in. 2011); 14 - przełomy w morenach czołowych fazy pomorskiej vistulianu (Szafraniec 2008, 2010a, 2010b); 15 - Pojezierze Suwalskie (Wysota i in. 2018)

Glaciofluvial sedimentation with rapid floods in proximal channels of braided rivers and on alluvial fans was described by Jaksa (2006) on the basis of several sites in central Poland, mainly in the Łask Heights. Documented profiles (e.g. Zygry, Leonardów) usually contain lithofacies sequences which provide evidence for the cyclical nature of the rapid floods in the marginal zone.They often occur in the form of gravelly bed covers or gravelly-sandy longitudinal outwashes.

On the basis of the characteristics of the bouldery-gravelly formations found in the outcrops of the cliff in Siedlątków on the Jeziorsko Reservoir, Rdzany (2009) and Frydrych (2014) presented a view on the possibility of a jökulhlaup occurrence there. They suggested that extreme flood flows could occur there as a result of unblocking of water during a glacial surge of the lobe developed in the middle Warta river basin.
Later studies by Frydrych (2016a, 2016b) into the structure of the esker near Rzymsko in the Turek Heights, several kilometres away from the sites in Siedlątków, provided evidence of the presence of lithofacies sequences which could be interpreted as a record of high-energy flows or even catastrophic subglacial floods, similar to jökulhlaup. This inspired further research in that area. It was conducted in the years 2016-2018, and concentrated on the record of extreme processes at four sites located in outcrops of the cliff on the Jeziorsko Reservoir in Siedlątków. It documented sedimentological record of the jökulhlaup which occurred there, in the form of erosional channels filled with bouldery-gravelly sediments, which resembles rapid floods in the marginal zones of Icelandic glaciers (Frydrych and Rdzany 2018). The thickness of the deepest channel reaches the maximum of about 10 metres. The jökulhlaup event took place during the recession of the Wartanian glaciation from the area of central Poland in the part of the glacial lobe which filled the Koło Basin, which is pre-Saalian. 
The occurrence of jökulhlaup resulted in forming erosional channels and filling them with glaciofluvial sediments. Their characteristic features are: erosional and deformational contact with substratum sediments, a high content of very coarse gravels and boulders, poorly sorted, dominance of massive structures, normal and inverse grading, and the presence of rip-up clasts. The main way of sediment transport was hyperconcentrated flow, with a lesser importance of debris flow and normal stream flow. Sudden water discharges may have been facilitated by fast movement of ice masses with features of a surge, related to the local post-maximal phase of Wartanian ice sheet activation. Palaeohydraulic analysis allowed the glacial water flow velocity to be estimated at about $6 \mathrm{~m}^{*} \mathrm{~s}^{-1}$ in the largest channel (Frydrych and Rdzany 2018).

In relation to the site in Siedlątków village, the nearest place where high energy flows were documented (Frydrych 2016) is the Rzymsko esker in the Turek Heights. Its southernmost point is located $4.5-5 \mathrm{~km} \mathrm{NWW}$. The proximity between these sites encourages the explanation of interrelation between processes recorded in the glacial tunnel and in the proglacial zone. For this reason the authors attempted at determining whether there is any similarity between the sediments at Siedlątków sites and the sediments of the Rzymsko esker. The most important question is whether the lithofacies of massive boulders with gravels, which are a record of very high energy level, found at Siedlątków is an extension of the glaciofluvial material with similar grain size distribution which is present in the structure of the Rzymsko esker. These places are separated with the 3-kilometre wide Warta valley, where postglacial fluvial erosional processes interrupted the continuity of formations from the Wartanian glaciation. The location of these sites in relation to each other does not rule out such a possibility if we assume that meltwater flowing in the subglacial tunnel had to change direction by approximately $50-60^{\circ}$ and flow nearly exactly west to east. Therefore, a number of lithological features of sediments were compared.

It follows from the analysis conducted by Frydrych (2016) that the Rzymsko esker was formed in the most intense water discharge zone which was the subglacial channel. Lithofacies which were the record of the highest energy exhibit some properties which indicate the average flow velocity to have exceeded $4 \mathrm{~m}^{*} \mathrm{~s}^{-1}$ according to Costa (1983) formulae. The predominant mode of sediment transport in the Rzymsko esker was hydraulic flow, which was periodically transformed into hyperconcentrated flow. Nevertheless, the content of massive boulders with gravels units is relatively low. Characteristic features include the well-developed large-scale units of tabular cross stratification (gravels, boulders with gravels), which are practically absent at the Siedlątków site. The architecture of sediments there is definitely more elaborate and complex along the over 15-metre profile, which indicates relatively long-term, multi-seasonal flows. Additionally, a characteristic feature of this material, which formed the lithofacies during the most intense flows, is the very high content of Upper-Cretaceous rocks (30-87\%, 50\% on average). The presence of a subglacial channel, in which the esker was formed, and a very high content of clasts eroded from Cretaceous rocks of the Quaternary substratum in its sediments indicate not only the subglacial character of sediment transport, but also a complete dissection of older Pleistocene formation and even direct erosion in Upper-Cretaceous limestones and marls. For comparison, the sediments described in Siedlątków as a result of jökulhlaups, as well as glacial till in their vicinity contain only several percent of rocks of the local substratum (3.35\% on average). Another premise which can prove the identities of sediments from sites in Siedlatków and Rzymsko is the comparison of the shape and roundness of pebble clasts (Tab. 1). Gravels indicate clear differences in the degree of processing during transport. In the esker, transport resulted in an increased content of well rounded and oblate clasts in the analysed samples. This was to a large degree influenced by the higher content of local rocks.

The conducted analysis and comparison with other results of research into meltwater flow paths of mainly subglacial origin in the Koło Basin and the neighbouring areas, particularly with the results of geological charting, indicate a great complexity of this system (Fig. 2).

Table 1. Features of clasts in studied sites in Siedlątków (S1-S4) and in the Rzymsko esker

Tabela 1. Cechy klastów w badanych stanowiskach w Siedlątkowie (S1-S4) i ozie Rzymska

\begin{tabular}{lccc}
\hline & Rzymsko $(\mathrm{N}=330)$ & Siedlątków $(\mathrm{N}=610)$ & 0.762 \\
\hline Mean elongation ratio & 0.758 & 0.731 & 0.756 \\
\hline Mean flatness ratio & 0.638 & 0.745 \\
\hline Mean maximum projection sphericity & 0.665 & 0.572 \\
\hline Roundness & 0.705 & 3.35 \\
\hline Mean content of local rocks $(\%)$ & 50.0 & 0.583 \\
\hline
\end{tabular}



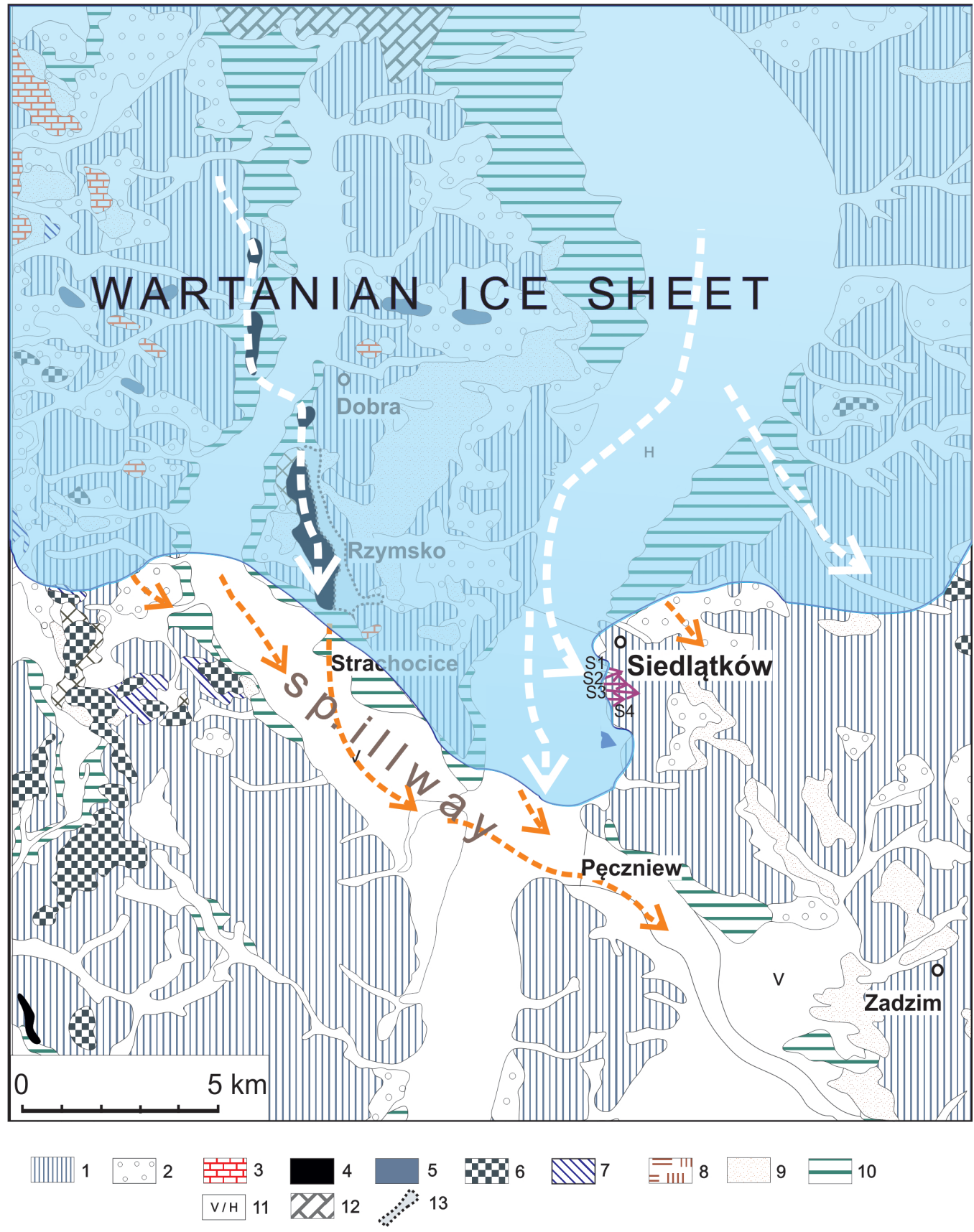

Fig. 2. Interpretation of the main routes of subglacial and proglacial flow system during the jökulhlaup near Siedlątków. White arrows indicate the probable paths of meltwater in ice body, purple arrows - the paths of jökulhlaup waters in the marginal zone, orange arrows - proglacial waters of ice sheet foreland. Geomorphological forms on the basis of modified geomorphological sketch (Klatkowa and Załoba 1992; Klatkowa et al. 2007; Czyż et al. 2008; Kamiński and Forysiak 2001): 1 - moraine plateau, 2 - fluvioglacial plains, 3 - moraine hills, 4 - eskers, 5 - forms of crevasse accumulation, 6 - kames, 7 - kame terraces, 8 - glaciolacustrine plains, 9 - dunes and sand plains, 10 - high terrace, 11 - bottoms of river valleys and flood plains (V-Vistulian, $\mathrm{H}$ - Holocene), 12 - excavations, 13 - tunnel valleys and meltwater valleys, (S1-S4) the cliff of the Jeziorsko Reservoir and research sites

Ryc. 2. Interpretacja głównych szlaków przepływu subglacjalnego i proglacjalnego w czasie zjawiska jökulhlaupu w okolicy Siedlątkowa.

Białe linie oznaczają prawdopodobne szlaki przepływu wód ablacyjnych lądolodu, strzałki fioletowe - szlaki odpływu wód jökulhlaupu w strefie marginalnej, strzałki pomarańczowe - wody proglacjalne na przedpolu lądolodu. Formy rzeźby zestawiono na podstawie szkiców geomorfologicznych (Klatkowa i Załoba 1992; Klatkowa i in. 2007; Czyż i in. 2008; Kamiński i Forysiak 2001): 1 - wysoczyzna morenowa, 2 - równiny glacifluwialne, 3 - wzgórza morenowe, 4 - ozy, 5 - formy szczelinowe, 6 - kemy, 7 - terasy kemowe, 8 - równiny glacilimniczne, 9 - wydmy i pokrywy eoliczne, 10 - wysoka terasa, 11 - dna dolin rzecznych i równin zalewowych (V - vistulian, H - holocene), 12 - odsłonięcia, 13 - rynny lodowcowe i doliny wód roztopowych, (S1-S4) klif zbiornika Jeziorsko i stanowiska badawcze 
Orłowska (Godlewska 2014; Orłowska 2017) also presented a thesis of the possible occurrence of a jökulhlaup-type flood at the end of the Wartanian Glaciation on the basis of data from the Łuniew site near Siedlce, in southern Podlasie. Within the set of glacimarginal fans, she documented structures of a large-scale erosional channel, which was related to the release of subglacial water.

\section{Traces of glacial outburst floods in the young glacial zone}

There are relatively few known sites within the extent of the Vistulian glaciation which include traces of glacial floods. Most of them were documented using sedimentologic methods in outwash areas (e.g. the Grajewo site). Thick series of coarse sediments were described there, on the basis of which it was assumed that large floods, including ones with characteristics similar to Icelandic jökulhlaups, might have played an important role in the formation of outwash plain forms (Zieliński 1993, 2014; Zieliński and Van Loon 1999, 2000, 2003)

Similarly to the extent of the Odranian and Wartanian glaciations, the record of flood flows of glacial water in subglacial tunnels was also identified in the eskers of the Vistulian glaciation. At the Kluczkowo site near Świdwin, Gruszka et al. (2011) described an 8-metre deep and 40-metre wide erosional channel filled with sediments of the gravelly-bouldery complex, which was interpreted as a sediment of a very dense, turbulent flow of the hyperconcentrated flow type. Also in the Gostynin esker, Roman (2016) found sediments of high energy flows. Meltwater, in which they were transported could also have caused phenomena of jökulhlaup type in the marginal and proglacial zone of the ice sheet.

Szafraniec (2008, 2010a, 2010b), was the first to describe traces of glacial flood records on the basis of morphological analysis of the terrain (terrain profile analysis, interpretation of the relief intensity factor). She distinguished outwash plains shaped by high energy floods in Pomerania in the marginal zone of the Pomeranian phase of Vistulian glaciation (Fig. 1, sites: 13). She observed the occurrence of megadunes and interpreted some canyons in end moraines of the Pomeranian Phase as release paths of flood water from glacial gates and other outlets in the ice sheet front. The author also demonstrates a connection between the flood phenomena and glacial surges, which supposedly occurred very commonly in the Vistulian ice sheet during its recession from the LGM.

The most recent detailed morphological analyses of outwash plains - based on detailed digital elevation models - have revealed the presence of many forms characteristic of areas where megafloods occurred (Wysota et al. 2017, 2018). The authors identified meltwater erosional surfaces, large spillways, pitted outwashes, obstacle marks, linear clusters of kettle holes and megadunes. Such areas include the outwash areas of the Suwałki Lakeland in north-western Poland. On the basis of palaeohydraulic estimations of flow values, they conclude that one of the largest glacial floods documented to date could have taken place there.

\section{Discussion and conclusions}

It follows from the review of works which describe phenomena of extreme glacial floods in the area of Poland that the number of such works is relatively small (Fig. 1). In most cases the collected documentation is either of sedimentological character, without support from geomorphological documentation, or presents mainly geomorphological evidence. So far, no cases of such events have been documented in detail as regards both the relief and lithological characteristics.

Individual cases of evidence of glacial floods concern in the greatest degree the following: systems of channel flow (filling of $\mathrm{N}$-type channels), extreme flood flows which formed canyons in terminal moraine ridges, channels filled with bouldery-gravelly material in proximal parts of outwash plains, dissections and gravelly covers on ice-marginal fans, as well as traces of release of limnic reservoirs in dead ice zones under areal deglaciation.

The existing research results allow us to believe that the greatest chances of preserving the record of great floods in the form of an appropriate inventory of both forms and sediments occur in outwash plains, which is indicated by the works of Szafraniec (2010a, 2010b) and Wysota et al. $(2017,2018)$ among others.

It is probable that GLOF events, caused by releases of large reservoirs located in front of the ice sheet margin, were much more frequent than it has been documented in various scientific works. The favourable factor was the inclination of vast areas of terrain towards the ice sheet front, especially in the south of the Polish Lowland and in northern parts of Pomerania. Traces of such sedimentation have been preserved in many regions of Poland. These reservoirs could disappear in different ways but we should expect that their functioning often finished after the glacial or mineral barrier was broken and water could flow down one of the ice-marginal valley systems.

In ice-marginal valleys, high energy flood flows are evidenced by the erosional bouldery pavements and terraces. Among others, as early work as Kozarski (1962), which documents many outcrops which fill the Noteć-Warta ice-marginal valley, clearly showed frequent cases of bouldery-gravelly erosional pavements which underlie the sediments of ice-marginal valley terraces, as well as ones which occur upon terrace surfaces. This indicates a great importance of erosional events for the forming of an ice-marginal valley. At the same time, there is evidence for periodical occurrence of large ice-dammed lakes, which mainly occupy basin-like broadenings of ice-marginal valleys. The size of these objects makes it difficult to correlate reservoir sediments with traces of extreme flows. Besides, it was not always possible for coarse-grained erosional pavements to form because, as a rule, the drained lacustrine sediments were not rich in such material.

There is a number of premises to support the hypothesis of great significance of catastrophic glacial floods for the formation of the most part of the European Lowland's system of ice-marginal valleys presented by Wysota et al. (2018). 
Similar speculations may also be formed on the basis of well-analysed GLOF events to the south of Hannover, from the extent of the Early Saalian Drenthe ice sheet (Odranian) (Meinsen et al. 2011; Winsemann et al. 2015; Lang et al. 2018). A detailed reconstruction of great glacial floods, which were the result of releases of proglacial lakes of Weser and Münsterland in North Rhine-Westphalia, was conducted there.

Some significant megafloods were documented to the north of Poland. For instance, there was a sudden drainage of the Baltic Ice Lake during the final stage of the Younger Dryas (ca. 11700 cal. yr BP). It was presented by Jakobsson et al. (2007) and Johnson et al. (2010). The outflow lasted more than one year, resulted in the decrease of the water level by about $25 \mathrm{~m}$, reducing the area of the reservoir by as much as $1 / 5^{\text {th }}$ and the volume of water which was released to the Atlantic Ocean was estimated to reach $7800 \mathrm{~km}^{3}$. This event, comparable with megafloods related to the release of Missoula and Agassis lakes in North America, may have been the greatest flood in the history of the Pleistocene within the extent of the Scandinavian glaciations.

Attention must also be paid to the occurrence of a number of local phenomena, involving high energy flows, including extreme events, in a restricted area. This may be related for example with a local occurrence of torrential rain, which resulted in a flash flood. Such phenomena, despite their relatively local extent, can have a significant impact on the shaping of many elements of the marginal zone of the ice sheet.

The conducted review of sites and areas where evidence for high energy floods was found indicates that these processes might have played a very likely, important morphogenetic role. At the same time, it reveals significant gaps in the palaeogeographic knowledge and indicates the need to conduct further geomorphological, sedimentological and other types of research which will allow for a better determination of the role and importance of high energy meltwater flows in shaping the landscape of lowland areas. In particular, the main objectives for future studies should include identifying the role played by glacial outburst floods in both the immediate foreland of ice sheets and the ice-marginal valleys.

\section{References}

Björnsson, H., 1992. Jökulhlaups in Iceland: prediction, characteristics and simulation. Annals of Glaciology 16, 95-106.

Carrivick, J.L., 2011. Jökulhlaups: geological importance, deglacial association and hazard management. Geology Today 27, 133-140. DOI:10.1111/j.1365-2451.2011.00800.x.

Costa, J.E., 1983. Paleohydraulic reconstruction of flashflood peaks from boulder deposits in the Colorado Front Range. Geological Society of America Bulletin 94 (8), 986-1004.

Czyż, J., Forysiak, J., Kamiński, J., Klatkowa H., 2008. Objaśnienia do Szczegółowej mapy geologicznej Polski 1:50000, arkusz Dobra (587), PIG Warszawa, 1-44.

Fard, M.A., Gruszka, B., 2007. Subglacial conditions in a branching Saalian esker in north-central Poland. Sedimentary Geology 193, 3346. DOI:10.1016/j.sedgeo.2006.03.029.

Frydrych, M., 2014. Rekonstrukcja zdarzeń zapisanych w osadach odsłonięcia klifu w Siedlątkowie nad zbiornikiem Jeziorsko. Master thesis, Department of Physical Geography, Łódź University, 1-84.
Frydrych, M., 2016a. Structural and textural response to dynamics of fluvioglacial processes of the Rzymsko esker sediments, Central Poland. Geology, Geophysics \& Environment 42 (4), 411-428. DOI:10.7494/geol.2016.42.4.411.

Frydrych, M., 2016b. Sediments of high-energy meltwater flows: examples from Central Poland, Saalian Glaciation, [w:] Proceedings book of the Second International Scientific Conference GEOBALCANICA 2016, 10-12 June 2016, Skopje, Republic of Macedonia, 169-176.

Frydrych M., Rdzany Z., 2018. Sedimentary record of a Late Saalian jökulhlaup: Case study in Siedlątków outcrop, Central Poland. Sedimentary Geology 374, 85-97. DOI:10.1016/j.sedgeo.2018.07.007.

Godlewska, A., 2014. Dynamika lądolodu warty w strefie marginalnej na międzyrzeczu Krzny i Bugu w świetle analizy litofacjalnej (Dynamics of the younger Saalian ice sheet in the marginal zone in the Krzna and Bug interfluve in the light of lithofacies analysis). Wydawnictwo Uniwersytetu Marii Curie-Skłodowskiej, Lublin, 1-153.

Gruszka, B., Dobracka, E., Langer, A., 2011. Polygenetic esker in Kluczkowo near Świdwin, NW Poland, [w:] Pisarska-Jamroży M., Dobracki R. (red.), Osady glacigeniczne fazy pomorskiej od Uckermark po Równinę Białogardzką. Bogucki Wydawnictwo Naukowe, Poznań, 85-96.

Gudmundsson, M.T., Björnsson, H. Pálsson, F., 1995. Changes in jökulhlaup sizes in Grímsvötn, Vatnajökull, Iceland, 1934-91, deduced from in-situ measurements of subglacial lake volume. Journal of Glaciology 41, 263-272.

Jakobsson, M., Björck, S., Alm, G., Andrén, T., Lindeberg, G., Svensson, N.O., 2007. Reconstructing the Younger Dryas ice dammed lake in the Baltic Basin: Bathymetry, area and volume. Global and Planetary Change 57, 355-370.

Jaksa, A., 2006. Środowiska sedymentacyjne kemów regionu łódzkiego. Acta Geographica Lodziensia 92, 1-95.

Jaksa, Z., Rdzany, Z., 2002. Sedymentologiczny zapis dynamiki deglacjacji Wysoczyzny Rawskiej na przykładzie Wału Rylska (Sedimentological records of deglaciation dynamics of Rawa Upland exemplified by the structure of the Rylsk Ridge). Acta Universitatis Nicolai Copernici, Geografia XXXII - Nauki Matematyczno-Przyrodnicze 109, 169-181.

Johnson, M.D., Stahl, Y., Larsson, O., Seger, S., 2010. New exposures of Baltic Ice Lake drainage sediments, Götene, Sweden. GFF 132, 1-12.

Kamiński, J., Forysiak, J., 2011. Objaśnienia do Szczegółowej mapy geologicznej Polski 1:50000, arkusz Uniejów (588). PIG Warszawa, 1-35.

Klajnert, Z., Rdzany, Z., 1989. Glacifluwialna geneza wysokich poziomów terasowych w dolinie górnej Rawki między Kochanowem a Rawą Mazowiecką. Acta Geographica Lodziensia 59, 21-39.

Klatkowa, H., 1993. Niektóre cechy glacigenicznych osadów warty w środkowej Polsce. Acta Geographica Lodziensia 65, 99-140.

Klatkowa, H., Czyż, J., Forysiak, J., 2007. Objaśnienia do Szczegółowej mapy geologicznej Polski 1:50000, arkusz Szadek (625), PIG Warszawa, 1-31.

Klatkowa, H., Załoba, M., 1992. Objaśnienia do Szczegółowej mapy geologicznej Polski 1:50000, arkusz Warta (624). PIG, Warszawa, 1-40.

Kozarski, S., 1962. Recesja ostatniego lądolodu z północnej części Wysoczyzny Gnieźnieńskiej a kształtowanie się Pradoliny Noteci-Warty (Recession of the last ice sheet from northern part of Gniezno Pleistocene Plateau and formation of the ice-marginal valley of the rivers Noteć-Warta). Poznańskie Towarzystwo Przyjaciół Nauk, Wydział Matematyczno-Przyrodniczy, Prace Komisji Geograficzno-Geologicznej 2 (3), 1-154.

Lang, J., Lauer, T., Winsemann, J., 2018. New age constraints for the Saalian glaciation in northern central Europe: Implications for the extent of ice sheets and related proglacial lake systems. Quaternary Science Reviews 180, 240-259. DOI:10.1016/j.quascirev.2017.11.029.

Maizels, J., 1997. Jökulhlaup deposits in proglacial areas. Quaternary Science Reviews 16, 793-819.

Meinsen, J., Winsemann, J., Weitkamp, A., Landmeyer, N., Lenz, A., Dölling, M., 2011. Middle Pleistocene (Saalian) lake outburst floods in the Münsterland Embayment (NW Germany): impacts and magnitudes. Quaternary Science Reviews 30, 2597-2625.

Mojski, J.E., 2005. Ziemie polskie w czwartorzędzie. Zarys morfogenezy. PIG, Warszawa, 1-404. 
Nye, J., 1976. Water flow in glaciers: jökulhlaups, tunnels and veins. Journal of Glaciology 17, 181-207. DOI:10.1017/S002214300001354X.

Pagneux, E., Gudmundsson, M.T., Karlsdóttir, S., Roberts, M.J., 2015. Volcanogenic floods in Iceland: An assessment of hazards and risks at Őræfajökull and the Markarfljót outwash plain. IMO, IES-UI, NCIP-DCPEM, Reykjavik, 1-164.

Orłowska, A., 2017. Osady plejstoceńskich powodzi lodowcowych w strefie marginalnej lądolodu warty we wschodniej Polsce. XXIV Konferencja Naukowo-Szkoleniowa Stratygrafia Czwartorzędu Polski „Czwartorzęd pogranicza niżu i wyżyn w Polsce Środkowej”, 4-8.09.2017, Wawrzkowizna k/Bełchatowa, 111-113.

Rdzany, Z., 1997a. Kształtowanie rzeźby terenu między górną Rawką a Pilicą w czasie zaniku lądolodu warciańskiego. Acta Geographica Lodziensia, 73, 1-146. DOI: 10.13140/RG.2.1.4361.2885.

Rdzany, Z., 1997b. Glacilimniczna sedymentacja kemowa w kotlinie górnej Rawki i jej znaczenie rzeźbotwórcze. Acta Universitatis Lodziensis. Folia Geographica Physica 1, 221-228.

Rdzany, Z., 2006. Osady deglacjacyjne zlodowacenia warty we wschodniej części regionu łódzkiego (Sediments of the Warta ice-sheet deglaciation in the eastern part of the Łódź region). Przegląd Geologiczny 54 (4), 343-351.

Rdzany, Z., 2008. Procesy ekstremalne w zapisie osadów i form warciańskich regionu łódzkiego. Landform Analysis 8, 65-68.

Rdzany, Z., 2009. Rekonstrukcja przebiegu zlodowacenia warty w regionie łódzkim (Reconstruction of the course of the Warta glaciation in the Łódź Region). Wydawnictwo Uniwersytetu Łódzkiego, Łódź, 1-310. DOI: 10.13140/RG.2.1.4504.4965.

Roman, M., 2016. Sukcesja osadowa i etapy formowania ozu gostynińskiego, Równina Kutnowska, Centralna Polska. Annales Universitatis Mariae Curie-Skłodowska 71 (1), 9-27. DOI:10.17951/b.2016.71.1.9.

Russell, A.J., Marren, P., 1999. Proglacial fluvial sedimentary sequences in Greenland and Iceland: a case study from active proglacial environments subject to jökulhlaups, [w:] Jones, A.P., Tucker, M.E., Hart, J. (red.), The Description and Analysis of Quaternary Stratigraphic Field Sections 7. Quaternary Research Association, London, 171-208.

Salamon, T., 2009. Subglacjalne pochodzenie przełomowych dolin zachodniej części progu środkowotriasowego i ciągu pagórów okolic Gogolina. Przegląd Geologiczny 57 (3), 243-251.

Salamon, T., Wójcik, A., 2010. Development of a fore-mountain alluvial fan of the Olza River (southern Poland) during the Pleistocene. Annales Societatis Geologorum Poloniae 80, 39-52.

Szafraniec, J., 2008. Powodzie lodowcowe na Pomorzu: zapis w morfometrii powierzchni sandrowych. Landform Analysis 8, 73-77.

Szafraniec, J., 2010a. Próba oszacowania maksymalnych przepływów wód lodowcowych lądolodu Wisły na Pomorzu. Landform Analysis 13, 107-115.
Szafraniec, J., 2010b. Zastosowanie wskaźnika urzeźbienia powierzchni sandrowych jako informacji o charakterze drenażu lądolodu Wisły na Pomorzu. Landform Analysis 13, 117-128.

Tweed, F.S., Russell, A.J., 1999. Controls on the formation and sudden drainage of glacier-impounded lakes: implications for jökulhlaup characteristics. Progress in Physical Geography 23, 79-110.

Waitt, R.B., Jr., 1988. About Forty Last-Glacial Lake Missoula Jökulhlaups Through Southern Washington. Journal of Geology 88, 653-679.

Winsemann, J., Alho, P., Laamanen, L., Goseberg, N., Lang, J., Klostermann, J., 2015. Flow dynamics, sedimentation and erosion of glacial lake outburst floods along the Middle Pleistocene Scandinavian Ice Sheet (northern central Europe). Boreas 45, 260-283.

Wysota, W., Weckwerth, P., Adamczyk, A., Krawiec, A., Dąbrowski, M., 2017. Geomorphological evidences of Late Pleistocene glacial megafloods in north-east Poland, [w:] Sarala, P., Johansson, P. (red.), From past to present - Late Pleistocene, last deglaciation and modern glaciers in the centre of northern Fennoscandia. INQUA Peribaltic Working Group Meeting and Excursion 2017, 20-25 August 2017, 173.

Wysota, W., Weckwerth, P., Adamczyk, A., Joeck M., Sobiech M., Krawiec, A., Dąbrowski, M., 2018. Late Weichselian catastrophic glacial floods in North Poland: geomorphologic signature and palaeogeographic implications. Lateglacial-Interglacial transition: glaciotectonic, seismoactivity, catastrohic hydrographic and landscape changes, [w:] INQUA Peribaltic Working Group Meeting and Excursion 2018, 19-25 August 2018, 122-123.

Załoba, M., 1996. Ślady oscylacji lądolodu warciańskiego we wschodniej części międzyrzecza Warty i Prosny. Acta Geographica Lodziensia 71, 275-288.

Załoba, M., Czubla, P., 1994. Siedlątków site. Profile of the glacigenic deposits against the background of geology and paleogeography of the Uniejów Basin. Glacitectonic structures, INQUA-SEQS, Symposium "The Cold Warta Stage - Lithology, Palaeogeography, Stratigraphy", Excursion Guide Book, Łódź, 21-29.

Zieliński, T., 1992. Proglacial valley facies of the Silesian Upland genetic factors and their sedimentological effect. Geol. Sudet. 26, 83-118.

Zieliński, T., 1993. Sandry Polski północno-wschodniej - osady i warunki sedymentacji. Uniwersytet Śląski 1398, 1-96.

Zieliński, T., 2014. Sedymentologia. Osady rzek i jezior. Adam Mickiewicz University Press, Poznań, 1-594.

Zieliński, T., Van Loon, A., 2000. Subaerial terminoglacial fans III: overview of sedimentary characteristics and depositional model. Geologie en Mijnbouw 79, 93-108.

Zieliński, T., Van Loon, A., 2003. Pleistocene sandur deposits represent braidplains, not alluvial fans. Boreas 32, 590-611. 